Proceedings of the International Scientifical Conference. Volume II: Social and Special pedagogy; Health and Sport; Overviews.

\title{
ADAPTATION PERIOD OF PUPILS: SOCIO-PEDAGOGICAL ASPECT
}

\author{
Skolēnu adaptācijas periods: sociālpedagoğiskais aspects
}

\author{
Rita Ukstina \\ Liepaja University, Latvia \\ E-mail: rita.ukstina@liepu.lv
}

\begin{abstract}
Analyzing the causes of academic failure of the first class pupils, the child's inability to get involved in the mainstream class is often mentioned as one of them which comes along with low self-esteem and mistrust in his/her intellectual abilities. Therefore in recent years, one of the research fields of social pedagogues is child's adaptation in the first class. This study analyzes the knowledge of various authors on factors that determine the psychological and social adaptation of the child in socio-pedagogical perspective. Theoretical aspects of adaptation are explored in order to determine the causes which hinder successful adaptation, and socio-pedagogical theories are analyzed elaborating support models for the whole class, teachers, parents and individual children.

The aim: to analyze theoretically social and psychological aspects of adaptation of pupils and describe the possible optimal socio-pedagogical activities for fostering adaptation of the first class pupils.

The research question: Professional complex socio-pedagogical help in adaptation process (to the whole class, individual pupils, teachers and parents) can provide successful adaptation of pupils at school.

The methodological base of the research consists of knowledge of different authors (P.Dako, A.Vorobjovs, H.Sellier, R.Bebre etc.) on social and psychological adaptation of pupils in new environment and spectrum of problems which appears when individuals are not able to adapt successfully at school; and knowledge of I.Plaude, J.Schilling, L.Beniss, N.Hupercs, E.Sinclers etc. on theoretical foundation of socio-pedagogical activities and its connection with the practice in the process of adaptation
\end{abstract}

Keywords: psychological adaptation, social adaptation, socio-pedagogical perspective.

\section{Introduction}

According to I.Puskarev (2001), adaptation means adjustment to environmental conditions and change of behaviour according to these conditions. Lack of adaptation can particularly be observed in the first years of life - for a child it is difficult to adapt to his/her parents, school environment, newborn brother or sister, etc. According to the author's opinion, lack of adaptation or failures can often cause neuroses and inner conflicts.

P.Dako (1999) sees human ability to adjust to different conditions as extremely valuable and as an essential sign of equilibrium.

H.Sellier (Plisko, 2001) suggests that adaptation allows the organism to achieve the "inner peace". Since the adaptation process includes not only the optimal functioning of the organism but also a successful balance in "organism environment" system, therefore the adaptation is always necessary in situations where there are changes in the system. As the "organism - environment" system is 
not static but in a dynamic process and within it the relationships are constantly changing, so the adaptation process should take place in the same way.

These theoretical conclusions already reveal the research topics of educators and social pedagogues and their activities, such as clarifying the adaptive capacity (level) of children and providing pedagogical assistance in cases connected with personality development.

According to R.Bebre (2000), adaptation includes social and psychological ability to deal with a situation when a person has to shift from a familiar agenda, accepted norms, values and social life of one social environment (preschool educational establishment) to another environment (school, classroom) with its new order and social life and with the need to learn a new social role - a pupil.

In order to assess children's readiness for school it is important to analyze the viewpoints and understanding of different authors on child's readiness for school. As noted by several authors, in this process the child's previous socialization experiences and acquired skills and abilities play the major role, as well as how competently organized the transition period is.

R.Kanepeja (2003), speaking about readiness of children for school, defines the main problem areas and also indicates how the goals can be reached. According to the author, "Personality formation process takes place under the impact of environmental education and development. The child actively learns about the world around (the nature, things, phenomena), how to behave in the world, forms attitude towards it and also the basic understanding about the values. The essence of child's development is embraced in wholeness of his/her development including concern for the health, physical and mental well-being. The child's development is formed by pedagogical activities of adults (correctly set goals and objectives, content, solution methods and techniques). It is important to remember that the child who has not been part of any group before, first must obtain skills to operate in it. Is necessary to ensure child's social development, which includes sensitivity towards others, knowledge of bad and good, careful attitude towards things, ability to communicate with peers and adults, ability to respect the opinions of others and offer one's own viewpoint, ability to independently choose activities and engage in play.

In turn R.Ukstina (2002), exploring the role of intellectual plays for child's readiness to school, points out that the child's ability to cooperate during the game, to accept the rules, being able to lose, etc. indicate the child's intellectual and social readiness for school.

D.Liegeniece (1999) emphasizes that during a play different aspects of child's development are simultaneously advanced and that the whole child's development determines his/her readiness for school. It is development of mental processes and personal characteristics which includes:

- ability to engage in common activities through cooperation;

- ability to perceive other person;

- desire to learn; 
Proceedings of the International Scientifical Conference. Volume II: Social and Special pedagogy; Health and Sport; Overviews.

- ability to finish work, to evaluate it.

Analysing the learning situation for children at school, it can be observed that the amount of lessons often is a reason for overloading the child, and that the large number of pupils in class makes it difficult for children to ask questions, express their thoughts, assumptions and hypotheses, which generally cause the frustration and does not correspond with their expectations from school. The elements of play appear at schools, but the teachers are claiming that the large number of pupils in class and limited premises make it difficult for them to organize the motion or didactic (intellectual) games.

In Latvia, in the directives for educational activities it is stated that primary school classrooms should have a play-zone where children can play in their free time or during the brakes between the lessons. I have some experience in creating such play environment in the first grade classroom together with the parents. I wanted to implement ideas of $\mathrm{M}$. Montessori in my research on learning possibilities with the help of didactic material, therefore once a week I organized activities following the method of M. Montessori. The project was not completed, but the play environment was created and it was welcomed by the class teacher and parents, but especially by the children themselves. Afterwards the class teacher pointed at the positive changes in children's relationships, their learning activity and behavioural changes. Intellectual and mathematical games improved the children's knowledge as well. This knowledge and how children were gradually introduced to the school life according to their pre-school experience was taken into account organizing socio-pedagogical activities for children in their adaptation process.

\section{Theoretical research of adaptation}

A.Vorobjovs (2002) defines adaptation as mastering behavioural norms, values, goals, communication and activity styles that are formed in the group, which means, when a person enters a new group, he/she must assess and learn the specifics of interpersonal relations and demands of the group. In this phase two alternatives are possible: either a person accepts the values of the whole group, that is, adapts in the group or he/she does not adjust to group values, which might be the cause of "exclusion" of the person from the group. In this case the person will be sort of "excluded" from the system of interpersonal relations, which in turn will slow down the adaptation process. In the group "outsiders" are always remain in adaptation phase without moving to the next phase. Due to this fact, the personality forms such traits of character as shyness, inferiority feelings or disbelief in oneself.

In the Dictionary of Sociology (2003) several developmental stages of adaptation are described.

Initial stage: an individual or group of individuals just begins to understand how they should behave in the new social environment in which they are in now, therefore they are not ready yet to accept and recognize the value system of a new environment and they try to stick to the value system of social environment 
that is familiar (I want to play; I already was in school yesterday, today I will go to the kindergarten, etc.).

Patience stage: both the individual and the social environment demonstrate some patience towards values and behaviour of both systems. At this stage, pupils should apply their moral and willpower qualities. If they are strengthened in preschool educational establishment and incorporation of these qualities continues in the adaptation period, then better results could be achieved.

Accommodation stage: the individual recognizes and accepts the basic elements of new social environment with the condition that social environment recognizes some of his/her individual values. If it does not happen this way, the pupil starts turning inwards and does not reveal his/her values at all.

Assimilation stage: complete congruence of value systems of an individual, social group and the surrounding environment.

Adaptation processes greatly depend on which stage they have reached in their development. These criteria must be taken into account assessing the adaptation stage of the pupils.

Adaptation can also be divided in several subjective and objective criteria. These criteria indicate to which degree an individual is integrated into new social environment and how much he/she is able or not able to accept conditions of the new community (class). Objective criteria indicate the degree to which an individual implements the norms and conditions of the new social environment, but subjective criteria - the satisfaction with the new social environment and conditions it offers, as well as possibilities for development.

There are also different types of adaptation. Regarding to adaptation in new school environment, these types are:

Psychological adaptation includes satisfaction of the current needs of an individual ensuring adequate human behaviour according to the demands of surrounding environment.

Social adaptation is an integrated indicator of personal readiness to undertake the necessary socio-biological functions and accept social roles in the group or community.

Socio-psychological adaptation means entering a new group, new environment and forming mutual relationship with other children and teachers. This process is characterized by active interaction, comparing of reciprocal values. During the adaptation process mutually acceptable relations are developed, but the most important objective indicator of socio-psychological adaptation is the absence of conflict between the social environment and the individual. This type of adaptation has already mentioned by R.Kanepeja (2003), D.Liegeniece (1999) etc.

According to I.Korobeinikov (2002), socio-psychological adaptation of the personality is possible on the basis of ontogenetic socialization, which can be defined as interaction of a person and social environment during which a person enters various problem-situations that arise in the sphere of interpersonal relationships. In this way, the individual learns the social norms of behaviour, 
Proceedings of the International Scientifical Conference. Volume II: Social and Special pedagogy; Health and Sport; Overviews. acquires skills, traits of character and other specific features which all are generally connected with adaptation. According to this author, the overcoming of each problem situation can be regarded as socio-psychological adaptation process of personality. I.Korobeinikov explains socio-psychological adaptation as interaction between a person and the group when a person without long-term external and internal conflicts efficiently perform his/her main activities, meet the basic social needs, fully moves towards the main expectations set by a model group, experience the state of self-assertion and free manifestation of his/her creative abilities.

Psychophysical adaptation means ability to adjust to work circumstances and demands. This adaptation is influenced by the condition of the organism and features of the nervous system. It is especially important for young school children as they often face adaptation difficulties and physical and mental stress; some children get ill particularly due to nervous tension (somatic illnesses). To assess the type of adaptation, social pedagogues are observing lessons and if necessary invite a medical nurse to join them. Children who have psychophysical adaptation problems should be approached by adults in a sensitive manner.

Adaptation can be divided in various stages. Dysfunctional stage takes place when a pupil gets acquainted with his/her new environment. The knowledge and skills of a pupil often do not correspond to the requirements of school, therefore the understanding from a teacher and differentiated work methods with pupils with different initial knowledge level are so significant. The attitude of parents towards the school and their children is of great importance as well. If the teachers and parents are not able to find a common approach for child's education, then social pedagogues should be involved as soon as possible.

Level of stereotypes is formed in interaction with environment in which a pupil learns the basic skills, adjusts to work setting and lives according to the environment in which he/she functions.

Every child is different therefore the adaptation forms are also different. These forms greatly depend on child's communicative abilities, attitude towards oneself and others, ability to involve in a new social group, and ability to accept the existing rules.

In psychology there is distinction made between active and passive social adaptation. Active social adaptation takes place when an individual tries to influence the surrounding environment with the aim to change it or to cause a reaction. Passive social adaptation means that the individual accepts his/her social role and does not want or simply do nothing to change anything. In this case, the support of a social pedagogue is necessary firstly by exploring the child's previous socialization experiences and problems that hinder his/her adaptation to the new environment and then by leading, motivating, supporting and helping the child to adapt to the school. 


\section{Theoretical background of socio-pedagogical work}

In socio-pedagogical work the aim for organizing adaptation period is to promote an effective inclusion of children in the school life.

In order to implement this goal, several objectives are set, which requires involvement and care of all teachers and other specialists (social pedagogue, psychologist, nurse, interest educator) working with the first grade pupils.

The work of social pedagogue is based on certain theories, principles and methods. To help the children to engage successfully into the class and social life, it is important to consider the theoretical base for this intervention (Peins, 2005)

Social development model points to family, school, friends and society as powerful resources for personality development.

Social learning theory, also called observation theory, emphasizes the importance of modelling behaviour, attitudes and emotional reactions of other children. This model can be employed for modelling positive behaviour.

Cognitive theory is based on social learning and is connected with thinking; therefore the task of social pedagogue is to help the pupil to change his/her thinking at the same time providing the learning experience. If a person is informed about negative consequences of a particular behaviour, he/she will be oriented towards constructive choices in order to change the behaviour.

Health belief model is oriented towards the change of behaviour, values and attitudes.

Social influence model emphasizes importance of social and individual risks and defence factors while forming relationships with other children and adults. Social influence can be created by peers, interest groups and also the family. This model is oriented towards acquiring and mastering social skills. In this process the example and support of adults and parents is vitally important, as well as selecting the right methods for developing and strengthening the social skills.

Socio-ecological model or ecological-environment model: in order to reach a stable and long-term behavioural change, the theory analyses and takes into account the social network of an individual (family, school, peers, society) and its influence on pupil's personality development, class environment, community support and development of positive family environment that can foster understanding about the role of the family in socialization process of children and improve socio-psychological climate at school and between the peers. This encourages attachment to school and helps to achieve the educational goals as well as develop positive relationships with the peers.

In their work, social pedagogues base their activities on theoretical knowledge on functions and operating principles of social pedagogues.

German authors N. Huppertz and E. Schinzler (1995) suggests the functions of social pedagogue which can be implemented when working with children. Some of these functions can be employed working with school children in order to foster adaptation. 
Proceedings of the International Scientifical Conference. Volume II: Social and Special pedagogy; Health and Sport; Overviews.

Prophylactic function: prophylactic work can be done to improve child's selfesteem, relations with the class, teachers and the family.

Organizational function: helping the class teachers to organize activities in which particular attention is paid to children who are under attention of social pedagogue, also organizing cooperation activities with parents.

Communicative function: ability to communicate with the children and other professionals. Diagnostic function: social pedagogue must try to identify causes of adaptation problems for each particular pupil in order to set the most effective tasks for intervention and organize the help.

Rights protection function: social pedagogues assess the situation of pupils both at home and school if their rights are not violated.

Social medical function: social pedagogue helps pupils when adaptation is connected with somatic illnesses due to nervous tension by involving the medical staff.

Consultative function: consultations are provided both for teachers and the families about cooperation and understanding children with adaptation difficulties.

Intermediary function: helping children to form relations with their peers, teachers and parents, and solve the conflicts.

Educational function: educating pupils, teachers and parents on various issues connected to learning, behavioural problems and social life.

School social pedagogues base their activities also on didactic and instructional principles. Several Russian authors have tried to adjust school didactic principles to social pedagogy from which the principles of individuality, regularity and the principle of gradualness can be mentioned as very important for prophylactic work with children.

In the process of adaptation the didactic principles elaborated by J. Schilling (1997) and upbringing principles of L. Beniss (4) are very helpful.

Firstly, J. Schilling mentions the principle of goal speaking about the goals of instruction and action which are set searching for causes of unsuccessful adaptation and also developing programs for help. When a pupil consciously gets involved in improving or changing his/her situation, we can speak about goals of action.

The next is the principle of "situation". Human activities always take place in situations. Also in this research adaptation is considered as "situation". J. Schilling suggests that the aim of social pedagogue is to create a situation in which positive learning of the client becomes possible (encouragement, motivation, recognition, engagement, participation. Also the environment in which the situation takes place needs to be explored, that is, school and class environment, family environment, and spare time environment. J. Schilling also distinguishes "internal and external situations". External situations are determined by factors of surrounding environment, but internal situations - "how I am feeling at the moment". For a social pedagogue it is important to learn how the children are feeling especially when they face adaptation difficulties. 
The next is the principle of process. Social pedagogues must be aware that no situations can be solved "now and at the moment". Therefore, J. Schilling distinguishes "time factor" and the "process in the group". Process in the group is a very important part of this principle because, as the author suggests, in the groups undergo several stages in their activity (in this case these are adaptation stages).

Another very important is the principle of relationships. According to the author, social pedagogue must develop relationships with the clients or group of the clients, at the same time preserving distance and treating everybody with respect. Pedagogical relations are developed employing three styles of leadership authoritarian, liberal and partner-oriented democratic style of leadership. In sociopedagogical work, for the student to arrive at self-realization, the partner-oriented leadership style should be exercised.

The last principle to be mentioned is the learning principle. If a social pedagogue manages to apply all above mentioned principles, then the pupil learns how to change his/her social situation. J. Schilling defines learning as follows: "Learning is obtaining, processing and releasing of different information". "Learning focuses on individual, making individuals as subjects of sociopedagogical assistance process, while upbringing in its usual sense too easy makes them as pure objects". In social pedagogy learning is understood as change of behaviour. There are two types of learning - intentional and functional. The first is a targeted learning, while the second is unconscious, informal learning, which implicitly takes over different behavior.

\section{Pedagogical aspects of adaptation}

The transition to the school stage is marked with significant qualitative changes in child's personality development (D. Liegeniece, R. Kanepeja, R. Bebre). It means a new status in the school, but this aspect has to be explored in the framework of whole range of changes - transition to a new stage of personality development and meaning of the new social role in the context of school and whole society.

The pupil must understand and accept the new social role (social learning model). This task employs promoting independence, initiative and joy of learning (cognitive theory).

It is important to learn how to get involved in the learning process (intentional learning). Starting cooperation in school, initial rules must be provided, that means all involved parties must agree on how this collaboration should take place. This includes formal rules that regulate the external side of the learning process - how to organize the workplace, what should be done during the lesson breaks. Also everybody has to join the learning process with their thinking and initiative - how to find the problem, how to search for solutions, how to cooperate with other pupils to solve a particular task. If the preschool educational establishment pays serious attention to preparation of children for school in the aspect of learning activities, then adaptation at school happens much more 
Proceedings of the International Scientifical Conference. Volume II: Social and Special pedagogy; Health and Sport; Overviews. successfully. There are also cases when everything goes sort of well in the preschool, but problems arise at school in terms of mutual relations, accepting evaluation or mutual cooperation. This can happen because of the change of status in the group which does not correspond anymore with the status that used to be in the preschool establishment. Successful adaptation program can help pupils to overcome the above mentioned difficulties.

At school the child's intellectual, physical and social abilities are constantly evaluated, so the school inevitably becomes a place where intensive development of the child's self-esteem begins. Relationships with peers determine pupil's attitude towards evaluation. In the beginning the evaluation is important to obtain a certain status at school, but if the status can be obtained with help of different values, then marks become less important. Social pedagogues particularly emphasize the meaning of assessment in formation of child's self-esteem. In first class there are no marks (points) given, but sometimes teachers are not happy about this fact. A situation can be mentioned when already on September 15 (at very beginning of the school year) a first-grader gets a negative comment about his/her behaviour and bad work in the class. The praxis showed that this child later had adaptation problems for several years, and it was professional, purposeful and systematic work of social pedagogues that helped this child to gain back his selfesteem (I am not only a loser).

Another case when the first class learner is emotionally stressed about not receiving an emblem which was given to pupils for being friendly. "I am a friendly girl!", says the girl. It shows how important is evaluation and how painful can be not getting a positive assessment because learning comes with difficulties. In this case social pedagogues concluded that this girl has not received sufficient preparation for school in the preschool establishment and she needs sociopsychological help for organizing her emotions, as well as individual help from teachers for learning particular subjects and psychological support from the parents.

According to D.Lasmane (2002), parents should understand their social role and they must be conscious about their responsibilities in the learning process. Parents must know and understand the goals, objectives and demands of school. The school must help the parents to understand how learning is going to take place, how the life in class and school is going to happen, and how parents can get involved in these processes.

The praxis and research of social pedagogues show that the parents of firstgraders are usually active and are listening well to the teachers, but gradually this interest decreases. There are several reasons for that. Firstly, parents get more distant if their children do not succeed at school too well, because then the parents receive negative comments, which make them to think that their children and parents themselves are losers. These children are also not praised by parents at home, and that makes the situation even worse. The work should be done with these parents and children, and in the case of necessity social pedagogues must step in. Social pedagogues also involve other pedagogues and other parents (consulting, 
experience exchange, educational and interest groups). Social pedagogues analyze causes on unsuccessful cooperation and develop cooperation programmes for parents individually or in the groups. Praxis proves that there can be very successful cooperation examples between parents and the school. Parents need to get acquainted with other parents that they would not fear to visit school and cooperate in the process of finding solutions for different issues.

According to A.Adler (1992), adaptation abilities do not last forever. Sometimes adaptation resources get drained after organism has been in transitionadaptation state for a while. In both cases dezadaptation starts which can take various forms:

- dezadaptation with insufficient reduction power, when ability to work remains but it is fragile and low.

- dezadaptation with a visible defect, which leads to reduction or loss of work abilities;

- dezadaptation with a hidden defect, which becomes visible only with the increase of intellectual load and when someone cannot adapt in the class environment.

The above mentioned dezadaptation forms can directly be attributed to adaptation problems of pupils in the school environment. Depending on existing life experience, the first dezadaptation form could be observed, which can quickly settle. A greater socio-pedagogical attention should be paid to the second and third dezadaptation form when the students lose their ability to learn, cannot find friends and generally feel very low.

Practical help to children can be given, if:

- pedagogues and social pedagogues are knowledgeable about theoretical aspects of adaptation process of an individual or a class;

- pedagogues and social pedagogues and parents are knowledgeable about development specifics of a particular age period;

- above mentioned specialists are knowledgeable about aspects of child's "SELF" development and are able to determine the level of its development;

- they are able to implement particular socio-pedagogical activities with the whole class, individual children or their parents in order to foster adaptation.

According to research studies, $80-85 \%$ of children adapt well, for approximately $15 \%$ adaptation takes more than a month, but about $5 \%$ face difficulties to get engaged in the class life, they feel lonely and not accepted for a long period of time. Organizing and implementing the adaptation programmes, these $5 \%$ of pupils become the individual clients of social pedagogues who work with them following the individual plan; but for other children adaptation programmes are implemented by teachers or social pedagogues.

Analysing the survey results, it was concluded that $75 \%$ of teachers consider as most important the satisfaction of children's cognitive needs, but only $12 \%$ social needs. $13 \%$ of teachers believe that it is important for pupils to understand their pupil's status. It shows that there are enough adaptation problems that need to 
Proceedings of the International Scientifical Conference. Volume II: Social and Special pedagogy; Health and Sport; Overviews. be addressed and therefore professional help should be given to the children. The research shows that the main attention of teachers is given to children's cognitive processes (learning), but little attention is paid to their personality development.

Practical socio-pedagogical models are elaborated in several bachelor and master's papers which show the essential problems of adaptation. The research on adaptation issues the students carry out during their field practice and also they implement socio-pedagogical adaptation models for groups and individuals. The questionnaires are used to learn the opinion of pre-school and school teachers and the parents, and also methods such as narrative conversations with children and observation of lessons in order to diagnose the adaptation problems of the whole class and individual children.

Based on adaptation programmes elaborated by various authors (G.Cukermane (2000), N.Polivanova (2000), I.Arvanova (2004), social pedagogues (A.Freibergs (2008), I.Puntule (2009), S. onaite (2007) u.c.) have elaborated and implemented in practice several socio-pedagogical adaptation models. They are:

- Observation of lessons of various subjects, when children are observed in order to specify the causes of adaptation difficulties.

- $\quad$ Purposeful conversations with pedagogues and parents to indicate the causes of adaptation difficulties

- Lesson complex led by class teacher or social pedagogues, or together. These are 2 hours per week during which children learn more about themselves, school, rules in the class, and develop cooperation skills with other children. It is important that those are not like regular lessons therefore they do not create stress or anxiety about not knowing something. This way a child obtains the balance between the required learning and the role of a student which implies getting along and cooperating with other children in the classroom.

- Professional individual help, which is given to the particular children with adaptation difficulties, and according to their needs, also the parents are involved or inter-professional cooperation is established.

This professional individual help is planned and organized on basis of psychological and pedagogical aspects of adaptation as well as on theoretical methodical aspects of socio-pedagogical work.

\section{Conclusions}

1. For a pupil the adaptation process is very complicated, sometimes even a process of crisis.

2. If the pupils at school do not find a supportive and friendly environment, friendly peers and teachers, they begin to lose interest in learning; they start feeling insecure, depressed, and are not able to create a positive interaction with others.

3. The theoretical research on adaptation indicates the importance of students' psychological, intellectual, and social and personality development. 
4. Research on pupils' adaptation problems indicate the need for schools to develop adaptation programs involving teachers, social pedagogues and, if necessary, other specialists in their implementation.

5. Socio-pedagogical activities are based on certain theories and principles in order to help social pedagogues to create successful adaptation models according to the assistance needed for a class or an individual.

6. Socio-pedagogical theoretical and practical experience, which is obtained through bachelor and master's papers in joint research with academic staff and is analyzed in field-practice and scientific conferences, shows that it helps pupils to overcome successfully the adaptation difficulties.

\section{Bibliography}

1. Ādlers, A. (1992). Psihologija un dzīve. - Rīga: IDea.

2. Arvanova, I. (2004). Adaptācijas aktualitāte 1. klasē //Skolotājs, Nr.5.

3. Bebre, R. (2000). Radošas personības adaptācija un neaptācija/ Sociālā pedagogija un personības psihologiskā adaptācija mainīgā sociālā vidē. -Rīga: Vārti.

4. Bēnišs, L. Bērnu un pusaudžu vecuma sociālā pedagogija. Ievads. - Rīga: SDSPA „Attīstība”.

5. Cukermane, G., Polivanova, N. (2000). Ievads skolu dzīvē. _Rīga: Pedagoǵiskais centrs „Eksperiments”.

6. Социология знциклопедия. - Минск: Книжний дом 2003.

7. Dako, P. (1999). Psihologijas brīnumainās uzvaras - Rīga: Zvaigzne ABC.

8. Es gribu iet skolāa/ autoru kolektīvs, Kaṇepējas R. red. - Rīga: SIA „Puse Plus”, 2003.

9. Hupercs, N., Šinclers, E.(1995.). Pedagoǵijas paatjautājumi / Ievads sociālas pedagogijas profesijām. /Basic questions of Pedagogy/- Izdevniecība Starn Kelne un Minhene.

10. Jonaite, S.(2007). Sociālā pedagoga loma bērnu adaptācijas sekmēšanā sākumskolā / magistra darbs, 2007.

11. Korobeinikov, I.(2002). Нарушение и соџиальная адаптащия. - М: Прогресс.

12. Lasmane D. (2002). Skolēnu adaptācijas process. Skolotājs , Nr. 32.

13. Lieǵeniece, D. (1999). Kopveseluma pieeja audzināšanā. -Rīga; Raka.

14. Martin, E. (1997). Didaktik der sozialpadagogischen Arbeit: Eine Einfuhrung in probleme und Moglichkeiten. Weinheim/Munchen.

15. Plaude, I. (2002) Sociālā pedagogíija. - Rīga: Raka.

16. Schilling, J. (1997). Soziale Arbeit: Entvicklungslinien der Socialpadagogik/ Sozialarbeit. Neuwied/Kriftel/Berlin.

17. Peins, M. (2005). Mūsdienu sociālā darba teorija.- Rīga: 'Attīstība'.

18. Plisko, A. (2001). Psihologiskāa adaptācija .-Rīga: Rosme.

19. Puntule, I. (2009). 10. klašu skolēnu adaptācija jaunā mācību vidē / maǵistra darbs.

20. Puškarevs, I. (2001). Attīstības psihologija. - Rīga: Raka.

21. School Social Work, Practice, Policy and Research Perspectives, tulkota latviski SIA ,J.L.V., 2001.

22. Skidmore, R. (1994.). Social Case Work Administration: Dynamic Management on Human Relationship / Ed. Fifer.- USA: Allyn\& Bacon.

23. Ukstiņa, R. u.c.(2002). Ģimeņu izglītība sociālajā pedagog̣ijā. - Rīga: Raka. 
Proceedings of the International Scientifical Conference. Volume II: Social and Special pedagogy; Health and Sport; Overviews.

24. Ukstiņa, R. (2002). Intelektuālo spēlu izmantošana $6-7$ gadus vecu bērnu pašvērtējuma veidošanā / zin.r "Bērna identitātes veidošanās piormsskolas vecumā. Liepāja: LiePA, 123 - 137.lpp.

25. Vilciña, A.(2008). Sadarbības un mijiedarbības ietekme uz sociālā pedagoga darbību / Dzīves jautājumi Nr. 8. - R.: Attīstība, 131. - 139. lpp.

26. Vorobjovs, A.(2002). Sociālā psiholoǵija.- Rīga: SIA ’Izglītības soḷi” .

\author{
Rita Ukstina Liepaja University \\ Liela st.14, Liepaja, LV-3401, Latvia \\ E-mail: rita.ukstina@liepu.lv
}

